\title{
The Lipid Parameters and Lipoprotein(a) Excess in Hashimoto Thyroiditis
}

\author{
D. O. Yetkin ${ }^{1}$ and B. Dogantekin ${ }^{2}$ \\ ${ }^{1}$ Department of Endocrinology, Kolan International Hospital, 36384 Istanbul, Turkey \\ ${ }^{2}$ Department of Internal Medicine, Goztepe Education and Research Hospital, 34722 Istanbul, Turkey \\ Correspondence should be addressed to D. O. Yetkin; demetozgil@yahoo.com
}

Received 12 February 2015; Revised 16 April 2015; Accepted 19 April 2015

Academic Editor: Franco Veglio

Copyright (c) 2015 D. O. Yetkin and B. Dogantekin. This is an open access article distributed under the Creative Commons Attribution License, which permits unrestricted use, distribution, and reproduction in any medium, provided the original work is properly cited.

\begin{abstract}
Objective. The risk of atherosclerotic heart disease is increased in autoimmune thyroiditis, although the reason is not clear. Lipoprotein(a) (Lp(a)) excess has been identified as a powerful predictor of premature atherosclerotic vascular diseases. The aim of this study is to investigate the relationship between $\mathrm{Lp}(\mathrm{a})$ levels and thyroid hormones in Hashimoto patients. Method. 154 premenopausal female Hashimoto patients (48 patients with overthypothyroid $(\mathrm{OH}), 50$ patients with subclinical hypothyroid (SH), and 56 patients with euthyroid Hashimoto to $(\mathrm{EH})$ ) were enrolled in this study. The control group consists of 50 age matched volunteers. In every group, thyroid function tests and lipid parameters with $\mathrm{Lp}$ (a) were measured. $\mathrm{Lp}(\mathrm{a})$ excess was defined as $\mathrm{Lp}(\mathrm{a})$ $>30 \mathrm{mg} / \mathrm{dL}$. Results. Total-C, LDL-C, TG, and Lp(a) levels were increased in Hashimoto group. Total-C, LDL-C, and TG levels were higher in SH group than in the control group. Total-C and LDL-C levels were also higher in EH group compared to controls. Lp(a) levels were similar in $\mathrm{SH}$ and $\mathrm{EH}$ groups with controls. However, excess $\mathrm{Lp}$ (a) was more common in subclinical hypothyroid and euthyroid Hashimoto group than in the control group. Conclusion. The Total-C and LDL-C levels and excess Lp(a) were higher even in euthyroid Hashimoto patients. Thyroid autoimmunity may have some effect on Lp(a) and lipid metabolism.
\end{abstract}

\section{Introduction}

Thyroid hormones regulate the wide array of metabolic parameters [1]. They have significant effect on the synthesis, mobilization, and metabolism of lipids and lipoproteins [2]. Dyslipidemia is a common metabolic abnormality in patients with thyroid disease, in either the overt or the subclinical forms of the disease. It has been known that overt hypothyroidism is associated with premature coronary heart disease and one of the components of this assumed to be a deteriorated metabolism of atherogenic lipoproteins. Lipoprotein(a) $(\mathrm{Lp}(\mathrm{a}))$ is a very large protein molecule wrapped around, and linked by a disulphide bond to, a LDL-like particle. There is a strong relationship with $\operatorname{Lp}(\mathrm{a})$ and coronary heart disease, independent of the standard vascular risk factors [3]. Autoimmune thyroiditis (Hashimoto thyroiditis) is a very common disorder and it is the main reason for hypothyroidism [4]. There are considerable sufficient data between the overt hypothyroidism, dyslipidemia, and coronary heart disease, although there are conflicting reports on whether subclinical hypothyroidism or euthyroid autoimmune thyroid disease has any influence on the lipoprotein metabolism. Recently it was reported that thyroid autoimmunity may be an important mechanism for the occurrence of atherosclerosis [5] and it is well known that $\operatorname{Lp}(\mathrm{a})$ is one of the main risk factors for the atherosclerosis.

The aim of this study was to investigate the relationship of lipid parameters, $\mathrm{Lp}(\mathrm{a})$ levels, and thyroid hormones in Hashimoto thyroiditis patients.

\section{Patients and Methods}

One hundred and fifty-four premenopausal female Hashimoto patients with a mean age of $37.19 \pm 7.98 \mathrm{SD}$ years, followed up and treated in our outpatient clinic between July 2013 and October 2013, were enrolled in this study. Fortyeight patients had overt hypothyroidism (age: $35.79 \pm 7.29 \mathrm{SD}$ years), fifty patients had subclinical hypothyroidism (age: 
$36.8 \pm 8.19$ SD years), and fifty-six patients were euthyroid $(36.3 \pm 8.11 \mathrm{SD}$ years $)$. All patients were positive for both antithyroid peroxidase and antithyroglobulin autoantibodies. The control group consisted of 50 healthy volunteers with a mean age of $35.42 \pm 7.64$ SD years.

The diagnosis of overt hypothyroidism $(\mathrm{OH})$ was based on clinical findings, low serum free thyroxine (FT4) levels, and high serum thyroid stimulating hormone (TSH) concentrations. Subclinical hypothyroidism $(\mathrm{SH})$ was established in terms of TSH levels $\geq 4.2 \mathrm{mIU} / \mathrm{mL}$ and normal FT4 levels. Euthyroid Hashimoto (EH) was established as normal FT4 and TSH levels with only positive thyroid autoantibodies.

Patients and controls with diabetes mellitus, current and ex-smokers, obesity (body mass index $(\mathrm{BMI})>30 \mathrm{~kg} / \mathrm{m}^{2}$ ), liver disease and systemic illness, excessive alcohol consumption, and a known family history of primary hyperlipidemia were excluded from the study. None of the subjects were receiving treatment with estroprogestin therapy, diuretics, $\beta$ blockers or lipid lowering drugs, or other medications that might alter serum lipid parameters and thyroid functions. None of the patients were receiving thyroid treatment and lipid level determinations were done on initial presentation, before the treatment.

The simple index to determine insulin resistance [i.e., homeostasis model assessment $($ HOMA-R) $>$ or $=2.5$ ] was used [6], and subjects who were determined to be positive for insulin resistance according to this index were also excluded. The study was approved by local ethical committee. Written informed consent was obtained from all the subjects.

Blood samples were collected after an overnight fast from an antecubital vein. Chemiluminescence immunoassay was done to assess TSH (normal 0.4 to $4.2 \mathrm{mIU} / \mathrm{mL}$ ), free thyroxine (normal: 0.93 and $1.7 \mathrm{ng} / \mathrm{dL}$ ), free triiodotironin (normal: $2.5-4.3 \mathrm{ng} / \mathrm{mL}$ ), and serum autoantibodies against thyroglobulin (TgAb) (normal: $0-115 \mathrm{IU} / \mathrm{mL}$ ) and thyroid peroxidase (TPOAb) (normal: 0-34 IU/mL ECLIA (Modular Analytics E170; Roche Diagnostics)). The measurements of total cholesterol (Total-C) (normal: $130-200 \mathrm{mg} / \mathrm{dL}$ ), high density lipoprotein (HDL-C) (normal: $>50 \mathrm{mg} / \mathrm{dL}$ ), low density lipoprotein (LDL-C) (normal: $70-130 \mathrm{mg} / \mathrm{dL}$ ), and triglyceride (TG) (normal: 60-150 mg/dL) levels were determined by enzymatic methods. Lipoprotein(a) (normal 0$30 \mathrm{mg} / \mathrm{dL}$ ) was measured in turbidimetric method by spectrophotometry (CRONY, JOOLY 100). Lp(a) excess was defined as $\mathrm{Lp}(\mathrm{a})>30 \mathrm{mg} / \mathrm{dL}$ [7].

Data were analyzed by SPSS 14 (SPSS Inc., Chicago, IL, USA) software. Normality of the distribution of variables was controlled with Kolmogorov-Smirnov test. Continuous data were expressed as the mean \pm SD and median and interquartile ranges, when appropriate. One-way ANOVA, Mann-Whitney $U$, and Kruskal Wallis tests were used to compare the parametric and nonparametric data of the groups. Spearman's rho correlation test was used for correlation analysis. Significance was accepted if $P<0.05$.

\section{Results}

The demographic data and the laboratory results of the entire study group are summarized in Table 1.
HOMA levels were not different among groups. However BMI was found higher in $\mathrm{OH}$ group than $\mathrm{EH}$ and controls as expected. SH group had also higher BMI than the control group.

TSH levels were higher in $\mathrm{OH}$ group than the other groups $(P<0.0001)$. SH patients also have higher TSH levels than the EH and control groups $(P<0.0001$ and $P<0.0001)$. TSH levels were in normal limits in both control group and $\mathrm{EH}$ group; $\mathrm{EH}$ patients have slightly higher TSH values than the control group; however no statistical difference was found $(P=0.05)$ (Table 2$)$.

FT3 and FT4 levels were in normal limits in both EH and control groups and no difference was found in these parameters $(P=0.13$ and $P=0.08$, resp.) between two groups. Free T3 and FT4 levels were also in normal reference ranges in $\mathrm{SH}$ group. However, $\mathrm{SH}$ patients had lower FT4 and FT3 levels compared to $\mathrm{EH}(P<0.0001$ and $P=0.002$, resp. $)$ and control group $(P<0.0001$ and $P<0.0001)$. FT3 and TF4 levels were significantly lower in $\mathrm{OH}$ group than the other groups $(P<0.0001$ and $P<0.0001)$ as expected.

Total cholesterol, LDL-C, and TG levels were higher in total Hashimoto groups than the control group $(P<0.0001$ in each). HDL-C was similar among groups $(P=0.27) . \mathrm{OH}$ group has higher Total-C, LDL-C, and TG levels than EH and control group as expected $(P<0.0001)$. $\mathrm{OH}$ patients also had higher Total-C $(P=0.004)$, TG $(P=0.01)$, and LDL levels $(P=0.008)$ compared to $\mathrm{SH}$ group. $\mathrm{SH}$ group had higher Total-C $(P<0.0001)$, LDL-C $(P<0.0001)$, and TG levels $(P=0.001)$ than the control group (Table 3$)$. $\mathrm{SH}$ group also had higher Total-C $(P=0.02)$ levels than the $\mathrm{EH}$ group; however LDL-C $(P=0.08)$ and TG levels $(P=0.16)$ were similar to the $\mathrm{EH}$ group (Table 4$)$. On the other hand $\mathrm{EH}$ group has higher Total-C $(P=0.04)$ and LDL-C $(P=0.01)$ levels but similar TG $(P=0.05)$ levels to the control group.

$\mathrm{Lp}$ (a) levels were higher in total Hashimoto group than the control group $(P=0.005)$. $\mathrm{OH}$ patients had significantly higher $\mathrm{Lp}(\mathrm{a})$ levels compared to control group $(P<0.0001)$; also patients with excess $\mathrm{Lp}(\mathrm{a})$ were more common in $\mathrm{OH}$ than the control group $(P<0.0001)$. OH patients have similar $\mathrm{Lp}(\mathrm{a})$ levels to $\mathrm{SH}$ patients $(P=0.39)$ and $\mathrm{EH}$ group $(P=0.15)$; however, $\mathrm{Lp}(\mathrm{a})$ excess was more common in $\mathrm{OH}$ than the $\mathrm{EH}(P=0.01)$ group. Although $\mathrm{Lp}(\mathrm{a})$ levels were not different between $\mathrm{OH}$ and $\mathrm{SH}(P=0.86)$ group, excess $\mathrm{Lp}(\mathrm{a})$ was also similar $(P=0.32)$.

On the other hand $\mathrm{SH}$ group has similar Lp(a) levels $(P=0.86)$ to $\mathrm{EH}$ group and the control group $(P=0.07)$. In $\mathrm{SH}$ group excess $\mathrm{Lp}(\mathrm{a})$ was also similar to the $\mathrm{EH}$ group $(P=0.1)$. However, $\mathrm{SH}$ group has more $\mathrm{Lp}(\mathrm{a})$ excess than the control group $(P=0.001)$. Moreover $\mathrm{EH}$ patients also have similar $\operatorname{Lp}(\mathrm{a})$ levels to control group $(P=0.08)$, but in EH group excess Lp(a) was more common than in the control group $(P=0.03)$.

$\mathrm{Lp}$ (a) was positively correlated with Total-C $(P<0.0001$, $r=0.41)$, LDL-C $(P<0.0001, r=0.42)$, TG $(P=0.001$, $r=0.22)$, and TSH $(P=0.003, r=0.20)$ and also negatively correlated with FT4 $(P=0.003, r=-0.20)$. TSH was positively correlated with Total-C $(P<0.0001$, $r=0.40)$, LDL-C $(P<0.0001, r=0.38)$, and TG $(P=$ $0.005, r=0.19)$. FT4 was negatively correlated with Total-C 
TABLE 1: Demographic and laboratory results of the groups.

\begin{tabular}{|c|c|c|c|c|c|}
\hline & $\begin{array}{l}\text { Overt hypothyroid } \\
\quad n=48\end{array}$ & $\begin{array}{l}\text { Subclinical hypothyroid } \\
\qquad n=50\end{array}$ & $\begin{array}{l}\text { Euthyroid Hashimoto } \\
\qquad n=56\end{array}$ & $\begin{array}{l}\text { Control } \\
n=50\end{array}$ & $P$ \\
\hline Age $($ mean \pm SD) & $35.79 \pm 7.28$ & $36.80 \pm 8.19$ & $36.30 \pm 8.11$ & $35.42 \pm 7.64$ & 0.46 \\
\hline TSH (mIU/mL) & $\begin{array}{c}11.6 \\
\text { [IQR: 7.27-26.2] }\end{array}$ & $\begin{array}{c}7.25 \\
\text { [IQR: } 5.94-8.61] \\
\end{array}$ & $\begin{array}{c}2.39 \\
\text { [IQR: } 1.66-3.13] \\
\end{array}$ & $\begin{array}{c}1.88 \\
\text { [IQR: } 1.46-2.5]\end{array}$ & $<0.0001$ \\
\hline FT3 (ng/dL) & $2.09 \pm 0.37$ & $2.99 \pm 0.36$ & $3.19 \pm 0.2$ & $3.32 \pm 0.43$ & $<0.0001$ \\
\hline FT4 (ng/dL) & $\begin{array}{c}0.82 \\
\text { [IQR: } 0.69-0.89]\end{array}$ & $\begin{array}{c}1.08 \\
\text { [IQR: } 1.02-1.18]\end{array}$ & $\begin{array}{c}1.17 \\
\text { [IQR: } 1.07-1.23]\end{array}$ & $\begin{array}{c}1.20 \\
\text { [IQR: } 1.13-1.34]\end{array}$ & $<0.0001$ \\
\hline Total-C (mg/dL) & $228.16 \pm 38.91$ & $204.5 \pm 40.9$ & $183.6 \pm 31.5$ & $176.4 \pm 13.6$ & $<0.0001$ \\
\hline $\mathrm{TG}(\mathrm{mg} / \mathrm{dL})$ & $\begin{array}{c}138 \\
\text { [IQR: } 110-160]\end{array}$ & $\begin{array}{c}115 \\
\text { [IQR: } 82.7-133.2]\end{array}$ & $\begin{array}{c}98.5 \\
\text { [IQR: 76.7-140.7] }\end{array}$ & $\begin{array}{c}81.50 \\
\text { [IQR: 69.7-110] }\end{array}$ & $<0.0001$ \\
\hline HDL-C (mg/dL) & $57.10 \pm 13.73$ & $56.34 \pm 12.06$ & $56.69 \pm 11.66$ & $54.68 \pm 10.96$ & 0.274 \\
\hline LDL-C (mg/dL) & $\begin{array}{c}144.5 \\
\text { [IQR: } 120-166]\end{array}$ & $\begin{array}{c}134 \\
\text { [IQR: } 110-143]\end{array}$ & $\begin{array}{c}116 \\
\text { [IQR: 102-136.7] }\end{array}$ & $\begin{array}{c}108.5 \\
\text { [IQR: } 97.75-117]\end{array}$ & $<0.0001$ \\
\hline $\mathrm{Lp}(\mathrm{a})(\mathrm{mg} / \mathrm{dL})$ & $\begin{array}{c}32 \\
\text { [IQR: } 15-50.3]\end{array}$ & $\begin{array}{c}17.55 \\
\text { [IQR: } 12.8-53.5] \\
\end{array}$ & $\begin{array}{c}17.85 \\
\text { [IQR: } 15.5-38.20]\end{array}$ & $\begin{array}{c}17.45 \\
{[\text { IQR: } 10.95-22.0]}\end{array}$ & 0.003 \\
\hline $\begin{array}{l}\text { Excess Lp(a) } \\
\text { percent }(\%)\end{array}$ & $N: 25(52 \%)$ & $N: 21(42 \%)$ & $N=16(28 \%)$ & $N: 6(12 \%)$ & $<0.0001$ \\
\hline BMI $\left(\mathrm{kg} / \mathrm{m}^{2}\right)$ & $26.64 \pm 2.02$ & $26.36 \pm 2.22$ & $25.58 \pm 2.72$ & $24.9 \pm 2.52$ & $<0.0001$ \\
\hline HOMA & $1.76 \pm 0.54$ & $1.68 \pm 0.58$ & $1.73 \pm 0.55$ & $1.59 \pm 0.62$ & 0.22 \\
\hline
\end{tabular}

Normally distributed values are indicated as mean \pm SD; nonnormaly distributed values are indicated as median and interquartile ranges.

TSH: thyroid stimulating hormone, FT4: free thyroxin, Total-C: total cholesterol, TG: triglyceride, HDL: high density lipoprotein, LDL: low density lipoprotein, Lp(a): lipoprotein(a), and BMI: body mass index; HOMA for insulin resistance index.

$P$ values are the differences of total Hashimoto groups and control group.

$(P<0.0001, r=-0.38)$, LDL-C $(P<0.0001, P=0.38)$, and TG $(P=0.007 r=-0.18)$. However, FT3 was negatively correlated with Total-C $(P<0.0001, r=0.29)$ and LDL-C $(P=0.0001, r=0.29)$, but no correlation was found with TG $(P=0.138)$ and $\operatorname{Lp}(\mathrm{a})(P=0.058)$. There was no correlation between $\mathrm{Lp}(\mathrm{a})$ levels and thyroid autoantibodies $((P=0.054$, $r=0.19)$ for anti-TPO and for $(P=0.09, r=0.23)$ anti-TG).

\section{Discussion}

This cross-sectional study shows increased Total-C and LDLC, TG and Lp(a) levels in Hashimoto cohort compared with controls. $\mathrm{Lp}(\mathrm{a})$ was increased only in $\mathrm{OH}$ patients, although hyperlipoprotein(a)emia was more frequent in even euthyroid Hashimoto patients.

Hashimoto's thyroiditis (chronic autoimmune thyroiditis) is the most common cause of hypothyroidism in iodinesufficient areas of the world. Thyroid failure is seen in up to 10 percent of the population and its prevalence increases with age [4].

In hypothyroidism major cardiovascular changes occur. Decreased cardiovascular output and cardiac contractibility, increased peripheral vascular resistance, and reduced heart rate result in cardiovascular dysfunction. There are also significant changes in modifiable atherosclerotic risk factors such as dyslipidemia $[8,9]$.

Dyslipidemia is common in hypothyroidism. Hypothyroid patients have increased levels of Total-C and LDL-C [10]. This is due to decreased LDL receptors' activity, resulting in decreased catabolism of LDL and IDL [11]. Moreover, a decrease in lipoprotein lipase (LPL) activity is found in overt hypothyroidism which decreases the catabolism of TG rich lipoproteins; therefore $\mathrm{OH}$ patients showed to have increased TG levels $[1,11,12]$. In our cohort $\mathrm{OH}$ patients had increased Total-C, LDL-C, and TG levels compared to controls, in accordance with the literature. Also in $\mathrm{SH}$ patients reported to have increased Total-C and LDL-C [13-15]. In addition some studies have shown that, in $\mathrm{SH}$, dyslipidemia may also be accompanied with increased TG levels $[16,17]$. In our study, Total-C, LDL-C, and TG levels were higher in the SH than in the control group.

Interestingly, in our cohort $\mathrm{EH}$ patients also have increased LDL-C, Total-C, and TG levels compared to the control group. TSH levels in our $\mathrm{EH}$ patients were not different from the control group. However, most of $\mathrm{EH}$ patients' (35 of 56 patients; 62\%) TSH values were in highnormal range $(2-4 \mathrm{ng} / \mathrm{mL})$. It has been recently reported that TSH levels in the upper limits of the reference range, in patients with coronary heart disease, had adverse effect on lipid profile [18]. Michalopoulou et al. reported increased Total-C and LDL-C levels in subjects with high-normal TSH levels but with positive antithyroid antibodies [19]. Also in a prospective population based study it has been shown that high TSH levels within the reference range may be associated with adverse serum lipids. TSH levels may covary with blood pressure and lipid levels among people with apparently normal thyroid function [20]. Similarly a recent large cohort study showed that TSH in the upper limit of 
TABLE 2: Demographic and laboratory results of the euthyroid Hashimoto patients and the control group.

\begin{tabular}{|c|c|c|c|}
\hline & $\begin{array}{c}\text { Euthyroid } \\
\text { Hashimoto } \\
n=56\end{array}$ & $\begin{array}{c}\text { Control } \\
n=50\end{array}$ & $P$ \\
\hline $\begin{array}{l}\text { Age } \\
(\text { mean } \pm \text { SD })\end{array}$ & $36.3 \pm 8.11$ & $35.42 \pm 7.64$ & 0.49 \\
\hline $\begin{array}{l}\text { TSH } \\
(\mathrm{mIU} / \mathrm{mL})\end{array}$ & $\begin{array}{c}2.39 \\
\text { [IQR: } 1.66-3.13] \\
\end{array}$ & $\begin{array}{c}1.88 \\
\text { [IQR: } 1.46-2.50]\end{array}$ & 0.06 \\
\hline FT3 (ng/dL) & $3.19 \pm 0.2$ & $3.32 \pm 0.43$ & 0.13 \\
\hline FT4 (ng/dL) & $\begin{array}{c}1.17 \\
\text { [IQR: } 1.07-1.23] \\
\end{array}$ & $\begin{array}{c}1.20 \\
\text { [IQR: } 1.13-1.34] \\
\end{array}$ & 0.08 \\
\hline $\begin{array}{l}\text { Total-C } \\
(\mathrm{mg} / \mathrm{dL})\end{array}$ & $183.6 \pm 31.5$ & $176.4 \pm 13.6$ & 0.04 \\
\hline TG (mg/dL) & $\begin{array}{c}98.5 \\
\text { [IQR: 76.7-140.7] }\end{array}$ & $\begin{array}{c}81.50 \\
\text { [IQR: } 69.7-110.75]\end{array}$ & 0.05 \\
\hline $\begin{array}{l}\text { HDL-C } \\
(\mathrm{mg} / \mathrm{dL})\end{array}$ & $56.69 \pm 11.66$ & $54.68 \pm 10.96$ & 0.32 \\
\hline $\begin{array}{l}\text { LDL-C } \\
(\mathrm{mg} / \mathrm{dL})\end{array}$ & $\begin{array}{c}116 \\
\text { [IQR: 102-136.7] }\end{array}$ & $\begin{array}{c}108.5 \\
\text { [IQR: 97.75-117] }\end{array}$ & 0.01 \\
\hline $\begin{array}{l}\mathrm{Lp}(\mathrm{a}) \\
(\mathrm{mg} / \mathrm{dL})\end{array}$ & $\begin{array}{c}17.85 \\
\text { [IQR: } 15.5-38.20]\end{array}$ & $\begin{array}{c}17.45 \\
\text { [IQR: } 10.95-22.02]\end{array}$ & 0.94 \\
\hline $\begin{array}{l}\text { Excess Lp(a) } \\
\text { percent }(\%)\end{array}$ & $N=16(28 \%)$ & $N: 6(12 \%)$ & 0.03 \\
\hline BMI $\left(\mathrm{kg} / \mathrm{m}^{2}\right)$ & $25.58 \pm 2.72$ & $24.9 \pm 2.52$ & 0.19 \\
\hline HOMA & $1.73 \pm 0.55$ & $1.59 \pm 0.62$ & 0.22 \\
\hline
\end{tabular}

Normally distributed values are indicated as mean \pm SD; nonnormaly distributed values are indicated as median and interquartile ranges.

TSH: thyroid stimulating hormone, FT4: free thyroxin, Total-C: total cholesterol, TG: triglyceride, HDL: high density lipoprotein, LDL: low density lipoprotein, Lp(a): lipoprotein(a), and BMI: body mass index; HOMA for insulin resistance index.

$P$ values are the differences of euthyroid Hashimoto group and control group.

the reference range (above $2.5 \mathrm{mIU} / \mathrm{L}$ ) was associated with higher Total-C [21]. This phenomenon was supported by the HUNT study [20]. Also recently reported studies showed that autoimmunity may have some effect on dyslipidemia independent of the thyroid function [22]. In our cohort, the increased Total-C and LDL-C levels in EH patients imply that autoimmunity may have some adverse effect on lipid profile independent of the TSH value.

$\mathrm{Lp}(\mathrm{a})$ is a form of LDL-C in which $\mathrm{Lp}(\mathrm{a})$ and $\mathrm{ApoB}$ are covalently bound by a disulphide bridge; it may be particularly atherogenic and thrombogenic [23]. Several studies have pointed out that high $\mathrm{Lp}(\mathrm{a})$ levels are associated with atherosclerotic disease, including myocardial infarction [23, 24]. It was shown that $\mathrm{Lp}(\mathrm{a})$ levels are increased in patients with $\mathrm{OH}$ and decrease after LT-4 treatment [25]. However, most studies to date have not found significantly elevated $\mathrm{Lp}$ (a) levels in patients with $\mathrm{SH}$ and have not demonstrated any effect of LT- 4 treatment on serum Lp(a) concentrations [25-27]. It has been reported that euthyroid males and postmenopausal females with thyroid autoimmunity present with increased Lp(a), implying the role of thyroid autoimmunity in the $\mathrm{Lp}(\mathrm{a})$ metabolism [28]. In our study $\mathrm{Lp}(\mathrm{a})$ was increased
TABLE 3: Demographic and laboratory results of the subclinical hypothyroid and the control group.

\begin{tabular}{|c|c|c|c|}
\hline & $\begin{array}{c}\text { Subclinical } \\
\text { hypothyroid } \\
n=50\end{array}$ & $\begin{array}{l}\text { Control } \\
n=50\end{array}$ & $P$ \\
\hline $\begin{array}{l}\text { Age } \\
(\text { mean } \pm \text { SD })\end{array}$ & $36.80 \pm 8.19$ & $35.42 \pm 7.64$ & 0.31 \\
\hline $\begin{array}{l}\text { TSH } \\
(\mathrm{mIU} / \mathrm{mL})\end{array}$ & $\begin{array}{c}7.25 \\
\text { [IQR: } 5.94-8.61]\end{array}$ & $\begin{array}{c}1.88 \\
\text { [IQR: } 1.46-2.50]\end{array}$ & $<0.0001$ \\
\hline FT3 (ng/dL) & $2.99 \pm 0.36$ & $3.32 \pm 0.43$ & $<0.0001$ \\
\hline FT4 (ng/dL) & $\begin{array}{c}1.08 \\
\text { [IQR: } 1.02-1.18]\end{array}$ & $\begin{array}{c}1.20 \\
\text { [IQR: } 1.13-1.34]\end{array}$ & $<0.0001$ \\
\hline $\begin{array}{l}\text { Total-C } \\
(\mathrm{mg} / \mathrm{dL})\end{array}$ & $204.5 \pm 40.9$ & $176.4 \pm 13.6$ & $<0.0001$ \\
\hline $\mathrm{TG}(\mathrm{mg} / \mathrm{dL})$ & $\begin{array}{c}115 \\
\text { [IQR: 82.7-133.2] }\end{array}$ & $\begin{array}{c}81.50 \\
\text { [IQR: 69.7-110.75] }\end{array}$ & 0.001 \\
\hline $\begin{array}{l}\text { HDL-C } \\
(\mathrm{mg} / \mathrm{dL})\end{array}$ & $56.34 \pm 12.06$ & $54.68 \pm 10.96$ & 0.51 \\
\hline $\begin{array}{l}\text { LDL-C } \\
(\mathrm{mg} / \mathrm{dL})\end{array}$ & $\begin{array}{c}134 \\
\text { [IQR: } 110-143]\end{array}$ & $\begin{array}{c}108.5 \\
\text { [IQR: } 97.75-117]\end{array}$ & $<0.0001$ \\
\hline $\begin{array}{l}\mathrm{Lp}(\mathrm{a}) \\
(\mathrm{mg} / \mathrm{dL})\end{array}$ & $\begin{array}{c}17.55 \\
\text { [IQR: } 12.8-53.5]\end{array}$ & $\begin{array}{c}17.45 \\
\text { [IQR: } 10.95-22.02]\end{array}$ & 0.07 \\
\hline $\begin{array}{l}\text { Excess } \operatorname{Lp}(\mathrm{a}) \\
\text { percent } N \\
(\%)\end{array}$ & $N: 21(42 \%)$ & $N: 6(12 \%)$ & 0.001 \\
\hline BMI $\left(\mathrm{kg} / \mathrm{m}^{2}\right)$ & $26.36 \pm 2.22$ & $24.9 \pm 2.52$ & 0.03 \\
\hline HOMA & $1.68 \pm 0.58$ & $1.59 \pm 0.62$ & 0.43 \\
\hline \multicolumn{4}{|c|}{$\begin{array}{l}\text { Normally distributed values are indicated as mean } \pm \text { SD; nonnormaly } \\
\text { distributed values are indicated as median and interquartile ranges. } \\
\text { TSH: thyroid stimulating hormone, FT4: free thyroxin, Total-C: total choles- } \\
\text { terol, TG: triglyceride, HDL: high density lipoprotein, LDL: low density } \\
\text { lipoprotein, Lp(a): lipoprotein(a), and BMI: body mass index; HOMA for } \\
\text { insulin resistance index. } \\
P \text { values are the differences of subclinical hypothyroid and the control group. }\end{array}$} \\
\hline
\end{tabular}

in $\mathrm{OH}$ group, although $\mathrm{Lp}$ (a) levels were similar in $\mathrm{SH}, \mathrm{EH}$, and even in control group. However, $\mathrm{Lp}$ (a) excess, which we defined as $\mathrm{Lp}(\mathrm{a})>30 \mathrm{mg} / \mathrm{dL}$, was more frequent in $\mathrm{OH}$ group compared to other groups. Moreover the interesting point in this study, Lp(a) excess, was also more frequent in SC and even $\mathrm{EH}$ than the control group. According to this finding, we may speculate that autoimmunity may have an influence on the Lp(a) metabolism, even with the normal TSH levels.

In conclusion, this study shows that, in Hashimoto thyroiditis even in normal TSH values, dyslipidemia may occur and increased Total-C, TG, LDL-C, and Lp(a) excess may occur, which are the potential risk factors for atherosclerosis, considering the fact that these patients should be closely followed up in terms of cardiovascular events.

\section{Conflict of Interests}

The authors declare that there is no conflict of interests regarding the publication of this paper. 
TABLE 4: Demographic and laboratory results of the subclinical hypothyroid and euthyroid Hashimoto patients.

\begin{tabular}{|c|c|c|c|}
\hline & $\begin{array}{c}\text { Subclinical } \\
\text { hypothyroid } \\
n=50\end{array}$ & $\begin{array}{c}\text { Euthyroid } \\
\text { Hashimoto } \\
n=56\end{array}$ & $P$ \\
\hline $\begin{array}{l}\text { Age } \\
(\text { mean } \pm \mathrm{SD})\end{array}$ & $36.80 \pm 8.19$ & $36.3 \pm 8.11$ & 0.76 \\
\hline $\begin{array}{l}\text { TSH } \\
(\mathrm{mIU} / \mathrm{mL})\end{array}$ & $\begin{array}{c}7.25 \\
\text { [IQR: } 5.94-8.61]\end{array}$ & $\begin{array}{c}2.39 \\
\text { [IQR: } 1.66-3.13] \\
\end{array}$ & $<0.0001$ \\
\hline FT3 (ng/dL) & $2.99 \pm 0.36$ & $3.19 \pm 0.2$ & 0.02 \\
\hline FT4 (ng/dL) & $\begin{array}{c}1.08 \\
\text { [IQR: } 1.02-1.18] \\
\end{array}$ & $\begin{array}{c}1.17 \\
\text { [IQR: } 1.07-1.23 \text { ] }\end{array}$ & 0.01 \\
\hline $\begin{array}{l}\text { Total-C } \\
(\mathrm{mg} / \mathrm{dL})\end{array}$ & $204.5 \pm 40.9$ & $183.6 \pm 31.5$ & 0.02 \\
\hline $\mathrm{TG}(\mathrm{mg} / \mathrm{dL})$ & $\begin{array}{c}115 \\
\text { [IQR: 82.7-133.2] }\end{array}$ & $\begin{array}{c}98.5 \\
\text { [IQR: 76.7-140.7] }\end{array}$ & 0.16 \\
\hline $\begin{array}{l}\text { HDL-C } \\
(\mathrm{mg} / \mathrm{dL})\end{array}$ & $56.34 \pm 12.06$ & $56.69 \pm 11.66$ & 0.67 \\
\hline $\begin{array}{l}\text { LDL-C } \\
(\mathrm{mg} / \mathrm{dL})\end{array}$ & $\begin{array}{c}134 \\
\text { [IQR: 110-143] }\end{array}$ & $\begin{array}{c}116 \\
\text { [IQR: 102-136.7] }\end{array}$ & 0.08 \\
\hline $\begin{array}{l}\mathrm{Lp}(\mathrm{a}) \\
(\mathrm{mg} / \mathrm{dL})\end{array}$ & $\begin{array}{c}17.55 \\
\text { [IQR: } 12.8-53.5]\end{array}$ & $\begin{array}{c}17.85 \\
\text { [IQR: } 15.5-38.20]\end{array}$ & 0.86 \\
\hline $\begin{array}{l}\text { Excess } \operatorname{Lp}(\mathrm{a}) \\
\text { percent } N \text { : } \\
(\%)\end{array}$ & $N: 21(42 \%)$ & $N=16(28 \%)$ & 0.15 \\
\hline BMI $\left(\mathrm{kg} / \mathrm{m}^{2}\right)$ & $26.64 \pm 2.02$ & $23.58 \pm 2.72$ & 0.10 \\
\hline HOMA & $1.68 \pm 0.58$ & $1.73 \pm 0.55$ & 0.69 \\
\hline \multicolumn{4}{|c|}{$\begin{array}{l}\text { Normally distributed values are indicated as mean } \pm \text { SD; nonnormaly } \\
\text { distributed values are indicated as median and interquartile ranges. } \\
\text { TSH: thyroid stimulating hormone, FT4: free thyroxin, Total-C: total choles- } \\
\text { terol, TG: triglyceride, HDL: high density lipoprotein, LDL: low density } \\
\text { lipoprotein, Lp(a): lipoprotein(a), and BMI: body mass index; HOMA for } \\
\text { insulin resistance index. } \\
P \text { values are the differences of subclinical hypothyroid and euthyroid } \\
\text { Hashimoto group. }\end{array}$} \\
\hline
\end{tabular}

\section{References}

[1] C. V. Rizos, M. S. Elisaf, and E. N. Liberopoulos, "Effects of thyroid dysfunction on lipid profile," Open Cardiovascular Medicine Journal, vol. 5, pp. 76-84, 2011.

[2] M. Heimberg, J. O. Olubadewo, and H. G. Wilcox, "Plasma lipoproteins and regulation of hepatic metabolism of fatty acids in altered thyroid states," Endocrine Reviews, vol. 6, no. 4, pp. 590-607, 1985.

[3] J. Danesh, R. Collins, and R. Peto, "Lipoprotein(a) and coronary heart disease: meta-analysis of prospective studies," Circulation, vol. 102, no. 10, pp. 1082-1085, 2000.

[4] J. G. Hollowell, N. W. Staehling, W. Dana Flanders et al., "Serum $\mathrm{TSH}, \mathrm{T}_{4}$, and thyroid antibodies in the United States population (1988 to 1994): National Health and Nutrition Examination Survey (NHANES III)," Journal of Clinical Endocrinology and Metabolism, vol. 87, no. 2, pp. 489-499, 2002.

[5] M. M. Ciccone, G. De Pergola, M. T. Porcelli et al., "Increased carotid IMT in overweight and obese women affected by Hashimoto's thyroiditis: an adiposity and autoimmune linkage?” BMC Cardiovascular Disorders, vol. 10, article 22, 2010.
[6] D. R. Matthews, J. P. Hosker, A. S. Rudenski, B. A. Naylor, D. F. Treacher, and R. C. Turner, "Homeostasis model assessment: insulin resistance and $\beta$-cell function from fasting plasma glucose and insulin concentrations in man," Diabetologia, vol. 28, no. 7, pp. 412-419, 1985.

[7] P. J. Stubbs, M. Seed, D. Lane, P. Collinson, F. Kendall, and M. Noble, "Lipoprotein(a) as a risk predictor for cardiac mortality in patients with acute coronary syndromes," European Heart Journal, vol. 19, no. 9, pp. 1355-1364, 1998.

[8] S. Taddei, N. Caraccio, A. Virdis et al., "Impaired endotheliumdependent vasodilatation in subclinical hypothyroidism: beneficial effect of levothyroxine therapy," Journal of Clinical Endocrinology and Metabolism, vol. 88, no. 8, pp. 3731-3737, 2003.

[9] I. Klein and K. Ojamaa, "Thyroid hormone and the cardiovascular system," The New England Journal of Medicine, vol. 344, no. 7, pp. 501-509, 2001.

[10] G. J. Canaris, N. R. Manowitz, G. Mayor, and E. C. Ridgway, "The colorado thyroid disease prevalence study," Archives of Internal Medicine, vol. 160, no. 4, pp. 526-534, 2000.

[11] J. J. Abrams and S. M. Grundy, "Cholesterol metabolism in hypothyroidism and hyperthyroidism in man," Journal of Lipid Research, vol. 22, no. 2, pp. 323-338, 1981.

[12] W.-Y. Lee, J.-Y. Suh, E.-J. Rhee, J.-S. Park, K.-C. Sung, and S.-W. Kim, "Plasma CRP, apolipoprotein A-1, apolipoprotein B and Lp(a) levels according to thyroid function status," Archives of Medical Research, vol. 35, no. 6, pp. 540-545, 2004.

[13] R. Luboshitzky, A. Aviv, P. Herer, and L. Lavie, "Risk factors for cardiovascular disease in women with subclinical hypothyroidism," Thyroid, vol. 12, no. 5, pp. 421-425, 2002.

[14] F. Monzani, N. Caraccio, M. Kozàkowà et al., "Effect of levothyroxine replacement on lipid profile and intima-media thickness in subclinical hypothyroidism: a double-blind, placebo- controlled study," Journal of Clinical Endocrinology and Metabolism, vol. 89, no. 5, pp. 2099-2106, 2004.

[15] J. P. Walsh, A. P. Bremner, M. K. Bulsara et al., "Thyroid dysfuntion and serum lipids: a community-based study," Clinical Endocrinology (Oxford), vol. 63, pp. 670-675, 2005.

[16] F. Toruner, A. E. Altinova, A. Karakoc et al., "Risk factors for cardiovascular disease in patients with subclinical hypothyroidism," Advances in Therapy, vol. 25, no. 5, pp. 430-437, 2008.

[17] H. J. Milionis, A. P. Tambaki, C. N. Kanioglou, M. S. Elisaf, A. D. Tselepis, and A. Tsatsoulis, "Thyroid substitution therapy induces high-density lipoprotein-associated platelet-activating factor-acetylhydrolase in patients with subclinical hypothyroidism: a potential antiatherogenic effect," Thyroid, vol. 15, no. 5, pp. 455-460, 2005.

[18] X. Wanjia, W. Chenggang, W. Aihong et al., "A high normal TSH level is associated with an atherogenic lipid profile in euthyroid non-smokers with newly diagnosed asymptomatic coronary heart disease," Lipids in Health and Disease, vol. 11, article 44, 2012.

[19] G. Michalopoulou, M. Alevizaki, G. Piperingos et al., "High serum cholesterol levels in persons with 'high-normal' TSH levels: should one extend the definition of subclinical hypothyroidism?" European Journal of Endocrinology, vol. 138, no. 2, pp. 141-145, 1998.

[20] B. O. Asvold, T. Bjøro, and L. J. Vatten, "Associations of TSH levels within the reference range with future blood pressure and lipid concentrations: 11-year follow-up of the HUNT study," European Journal of Endocrinology, vol. 169, no. 1, pp. 73-82, 2013. 
[21] A. Boggio, F. Muzio, M. Fiscella, D. Sommariva, and A. Branchi, "Is thyroid-stimulating hormone within the normal reference range a risk factor for atherosclerosis in women?" Internal and Emergency Medicine, vol. 9, no. 1, pp. 51-57, 2014.

[22] G. Tamer, M. Mert, I. Tamer, B. Mesci, D. Kilic, and S. Arik, "Effects of thyroid autoimmunity on abdominal obesity and hyperlipidaemia," Endokrynologia Polska, vol. 62, no. 5, pp. 421428, 2011.

[23] D. J. Rader and H. B. Brewer Jr., "Lipoprotein (a): clinical approach to a unique atherogenic lipoprotein," Journal of the American Medical Association, vol. 267, no. 8, pp. 1109-1112, 1992.

[24] G. H. Dahlen, J. R. Guyton, M. Attar, J. A. Farmer, J. A. Kautz, and A. M. Gotto Jr., "Association of levels of lipoprotein Lp(a), plasma lipids, and other lipoproteins with coronary artery disease documented by angiography," Circulation, vol. 74, no. 4, pp. 758-765, 1986.

[25] T. Tzotzas, G. E. Krassas, T. Konstantinidis, and M. Bougoulia, "Changes in lipoprotein(a) levels in overt and subclinical hypothyroidism before and during treatment," Thyroid, vol. 10, no. 9, pp. 803-808, 2000.

[26] N. Caraccio, E. Ferrannini, and F. Monzani, "Lipoprotein profile in subclinical hypothyroidism: response to levothyroxine replacement, a randomized placebo-controlled study," Journal of Clinical Endocrinology and Metabolism, vol. 87, no. 4, pp. 1533-1538, 2002.

[27] M. Ito, J. Takamatsu, I. Sasaki et al., "Disturbed metabolism of remnant lipoproteins in patients with subclinical hypothyroidism," The American Journal of Medicine, vol. 117, no. 9, pp. 696-699, 2004.

[28] H. Lotz and G. B. Salabe, "Lipoprotein (a) increase associated with thyroid autoimmunty," European Journal of Endocrinology, vol. 136, pp. 87-91, 1997. 


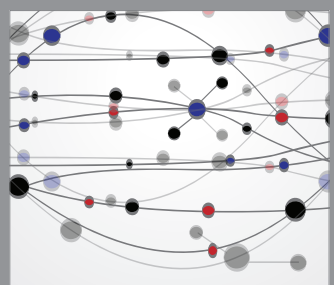

The Scientific World Journal
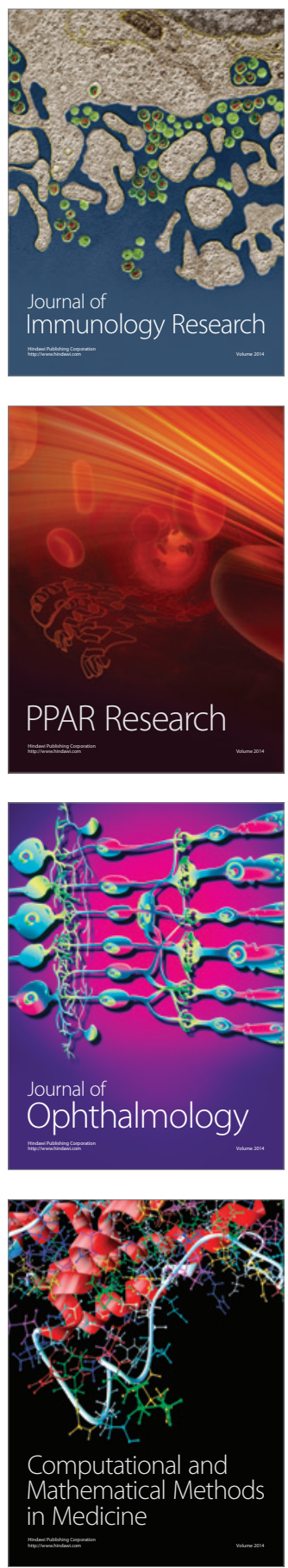

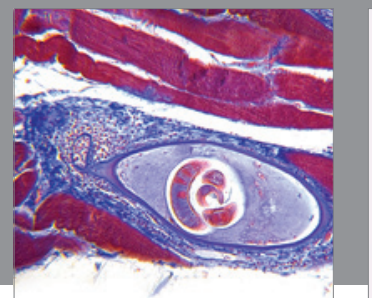

Gastroenterology

Research and Practice
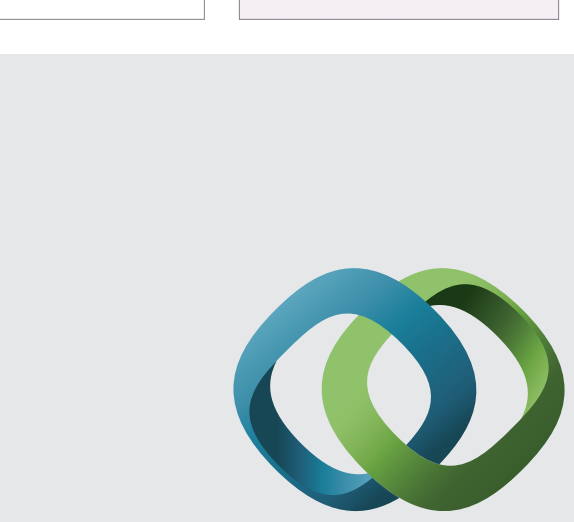

\section{Hindawi}

Submit your manuscripts at

http://www.hindawi.com
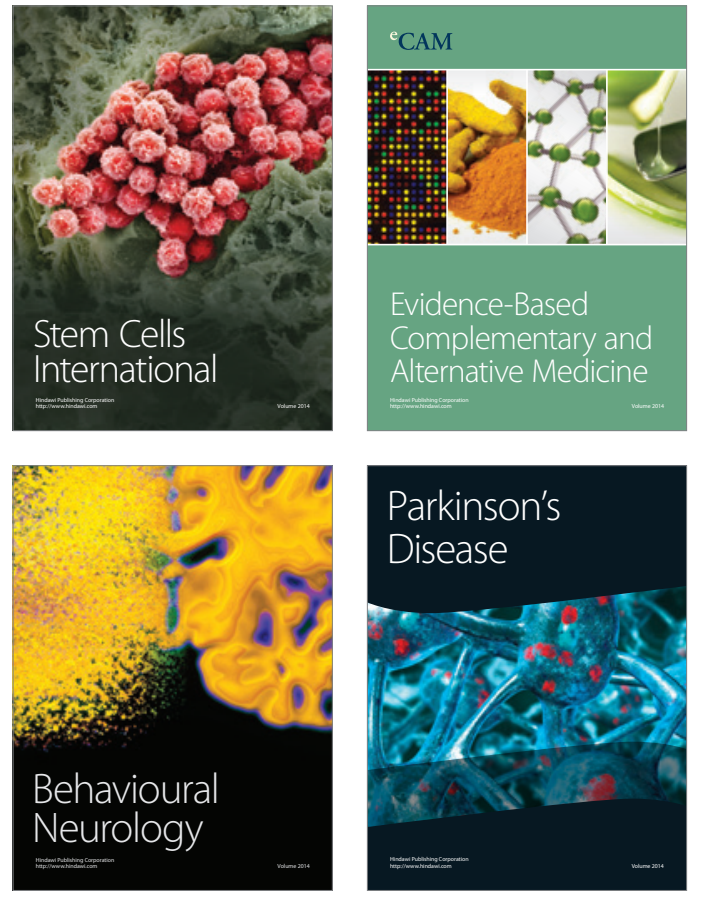
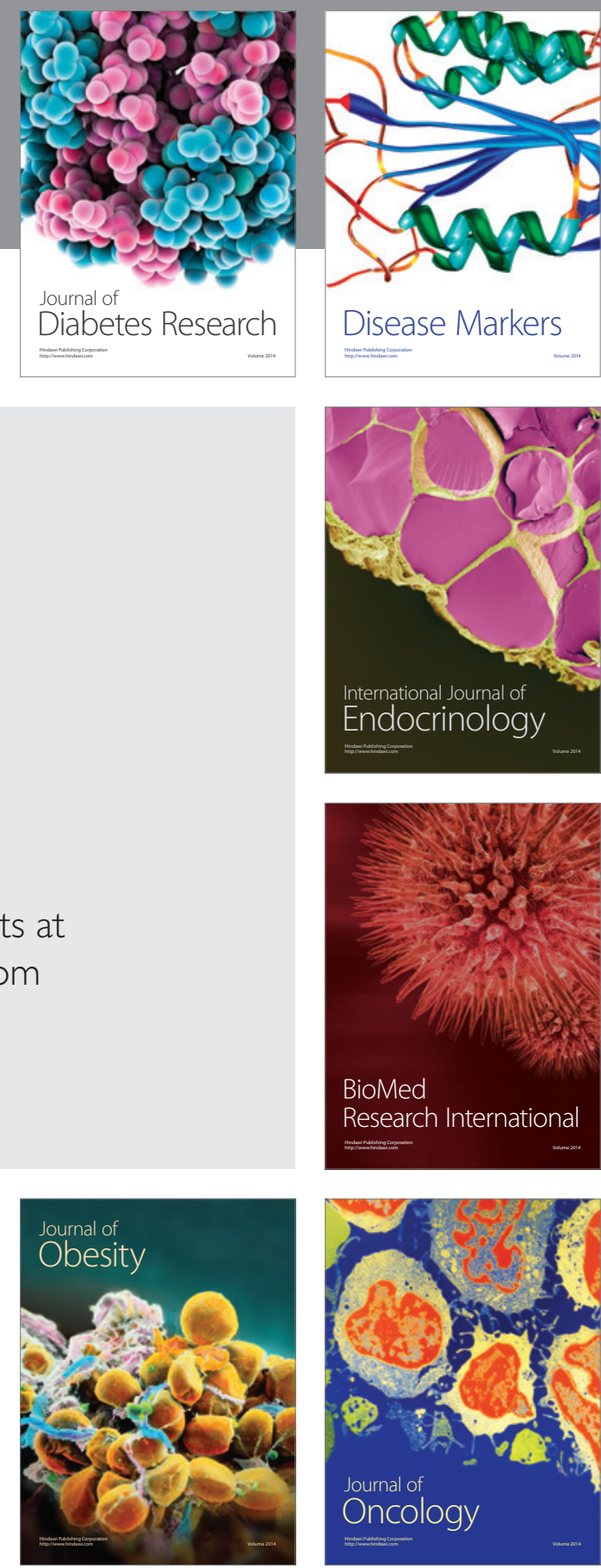

Disease Markers
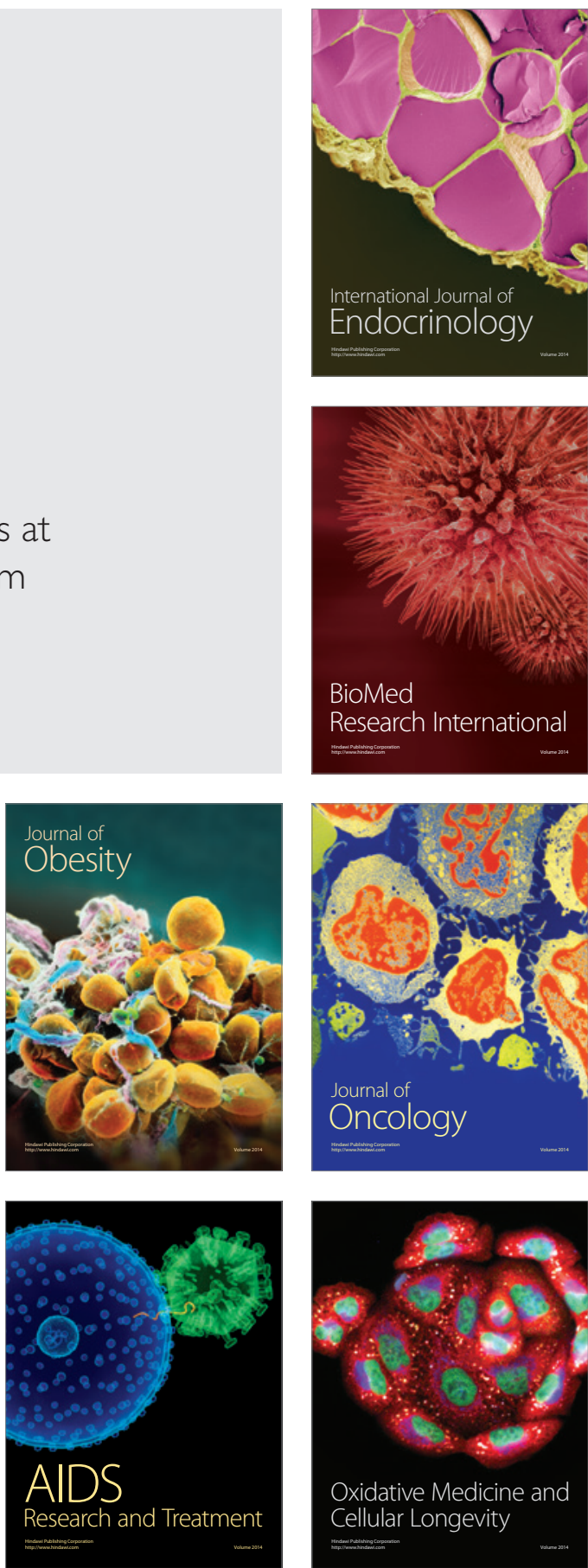